\title{
Development of Emission Factor Equations for Surface Mining Activities: The Case of the Stacker ${ }^{\dagger}$
}

\author{
Athanasios Triantafyllou ${ }^{1, * \mathbb{D}}$, Ioannis Kapageridis ${ }^{1}\left(\mathbb{D}\right.$, Stylianos Gkaras $^{2}$ and Francis Pavloudakis ${ }^{3}$ \\ 1 Department of Mineral Resources Engineering, University of Western Macedonia, 50132 Kozani, Greece; \\ ikapageridis@uowm.gr \\ 2 Department of Chemical Engineering, University of Western Macedonia, 50132 Kozani, Greece; \\ sgaras@uowm.gr \\ 3 Public Power Corporation of Greece SA, 50132 Kozani, Greece; f.pavloudakis@dei.com.gr \\ * Correspondence: atrianta@uowm.gr; Tel.: +30-24610-68244 \\ + Presented at International Conference on Raw Materials and Circular Economy, Athens, Greece, \\ 5-9 September 2021.
}

Citation: Triantafyllou, A.

Kapageridis, I.; Gkaras, S.;

Pavloudakis, F. Development of

Emission Factor Equations for Surface

Mining Activities: The Case of the

Stacker. Mater. Proc. 2021, 5, 15.

https: / / doi.org/10.3390/

materproc2021005015

Academic Editor: Evangelos Tzamos

Published: 16 November 2021

Publisher's Note: MDPI stays neutral with regard to jurisdictional claims in published maps and institutional affiliations.

Copyright: (c) 2021 by the authors. Licensee MDPI, Basel, Switzerland. This article is an open access article distributed under the terms and conditions of the Creative Commons Attribution (CC BY) license (https:// creativecommons.org/licenses/by/ $4.0 /)$.

\begin{abstract}
In surface mines, various activities (e.g., excavations, loading and unloading of material, moving vehicles on unpaved haul roads, etc.) represent significant sources of fugitive dust. The estimation of dust generation from each individual source is a basic step in planning and implementation decision-making systems regarding the air quality of the surrounding area. Typically, this can be obtained by using emission factor or prediction-type equations. A detailed study was carried out at four surface lignite mines to determine PM emission factors and to develop the prediction-type equations of various surface mining activities. In this work, the data, method and results referring to the stacker, one of and the significant fugitive dust emissions source in mining operations are presented and analyzed.
\end{abstract}

Keywords: fugitive dust; PMx; emission factor equations; air pollution; environmental management; surface mining

\section{Introduction}

A key element of environmental protection in areas where surface mines operate is addressing problems generated by the fugitive dust emitted from various mining operations. In mine planning, an estimate of dust generation is necessary to check the likely level of air pollution in the mining area due to proposed project activities [1].

Typically, this can be estimated by using emission factors or prediction-type equations for the development of emission factors. The latest provide a superior estimation of dust formation in opencast mines [2-4]. Emission factors are also required as input data in air quality models, which are useful to predict the concentrations of pollutants in air quality management-integrated systems. So, the accurate emission factor estimation is one of the critical problems in forming a strategy to control fugitive dust emissions.

The U.S. Environmental Protection Agency (EPA) published a compilation of air pollution emission factors, usually referred as AP-42, and emission factors equations for open dust sources at western surface coal mines $[5,6]$. It has been demonstrated that application of the U.S. emission estimation methods to other regions could lead to results with large uncertainties due to differences in the nature of mining, site practices, and mitigation measures, as well as geological and climatic conditions. As a result, experimentally based derivation of emission factors appropriate to the area and the activities under study is necessary for a reliable calculation of fugitive dust emissions.

The Greek Public Power Corporation and specifically the Lignite Center of Western Macedonia (GPPC/LCWM) funded a project named "THEOFRASTOS" to provide accurate quantification and prediction of mining-related PM10 and PM2.5 emissions and dispersion, which is a key input to environmental impact assessments and regulatory policy decisions. 
In the frame of this investigation, field measurements were conducted in the four major surface mines of Western Macedonia basin (mine of South field, mine of Kardia field, Mavropigi mine, Amyntaio mine), a lignite-bearing area in NW Greece. By using the reverse dispersion modeling (RDM) method and multiple regression analysis, emission factors were estimated, and emission factor equations were developed for selected mining activities. Finally, the total PM10 amount emitted from each individual mining activity, as well the total emitted by each mine for one year period, were computed $[7,8]$. A userfriendly emission software called "e-Theofrastos" was developed, calculating the mass of fugitive dust emission from the mining activities [9].

The findings are useful tools to predict air pollution before the commencement of any mining activity, and, thus, effective mitigating measures can be designed at the planning stage. The results have shown that, in the surface mining operations, the stackers, i.e., the large machines used in bulk material handling, are significant fugitive dust emissions sources. The development of an emission factor equation to calculate the PM10 emissions from this significant fugitive dust source in mining operations is presented and analyzed here.

\section{Materials and Methods}

Field monitoring, laboratory analysis, and modelling procedures used to derive reliable PMx emission factors. The methodology included the following:

- Mining details;

- Analysis of silt content;

- Moisture content determination;

- Measurement campaigns determining;

- PMx concentrations and meteorological magnitudes;

- Reverse dispersion modelling;

- Statistical data analysis;

- Emission factors evaluation;

- Development of emission factor equations;

- Validation of the equations;

- Development of s/w to calculate PM emissions.

The measurements campaign carried out by using five PMx monitors (Grimm) and meteorological sensors (Figure 1), during the cold and warm period, helped to assess the influence of varying meteorological conditions on emission factors. The emission factors were derived by the application of upwind/downwind differences and the reverse dispersion modelling method (RDM), according to international standards $[8,10]$.

For the development of emission factor equation, the emission factor calculated for different mining activities, or the stacker in this case (Figure 2), along with the key influencing parameters for four mines, were statistically analyzed by:

- Independent variable selection, data segregation, and tabulation;

- Multiple linear regression analysis (MLR) utilizing the natural logarithm of the variables. MLR was repeated so that outlier values were rejected until $p<0.05$ and $\mathrm{R}>0.8$ were achieved. 


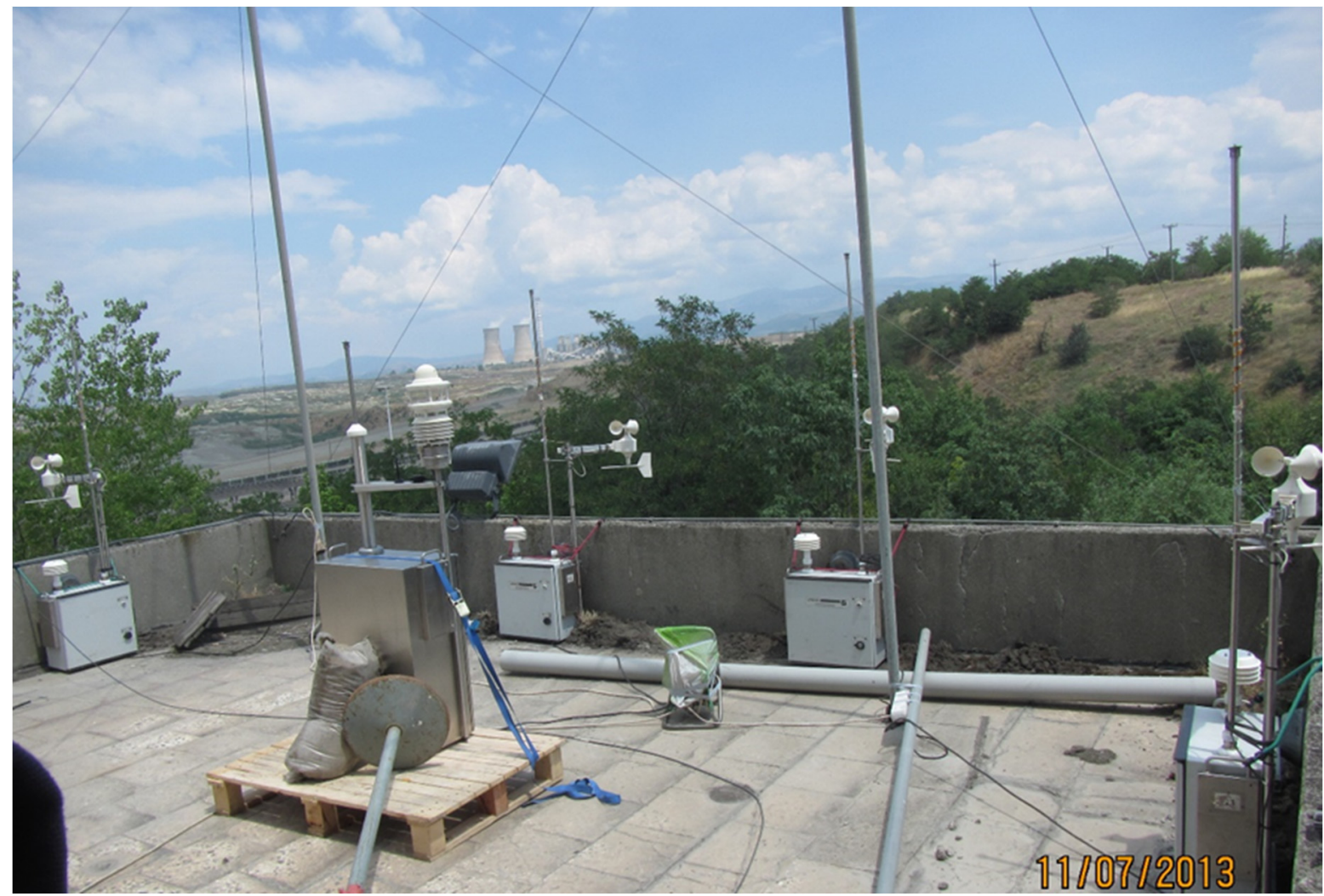

Figure 1. The five PMx monitors (Grimm) and meteorological sensors of used for the measurement campaign located on the roof of Amyntaio mine control tower. Intercomparison of equipment performed at the start of each measurement period.

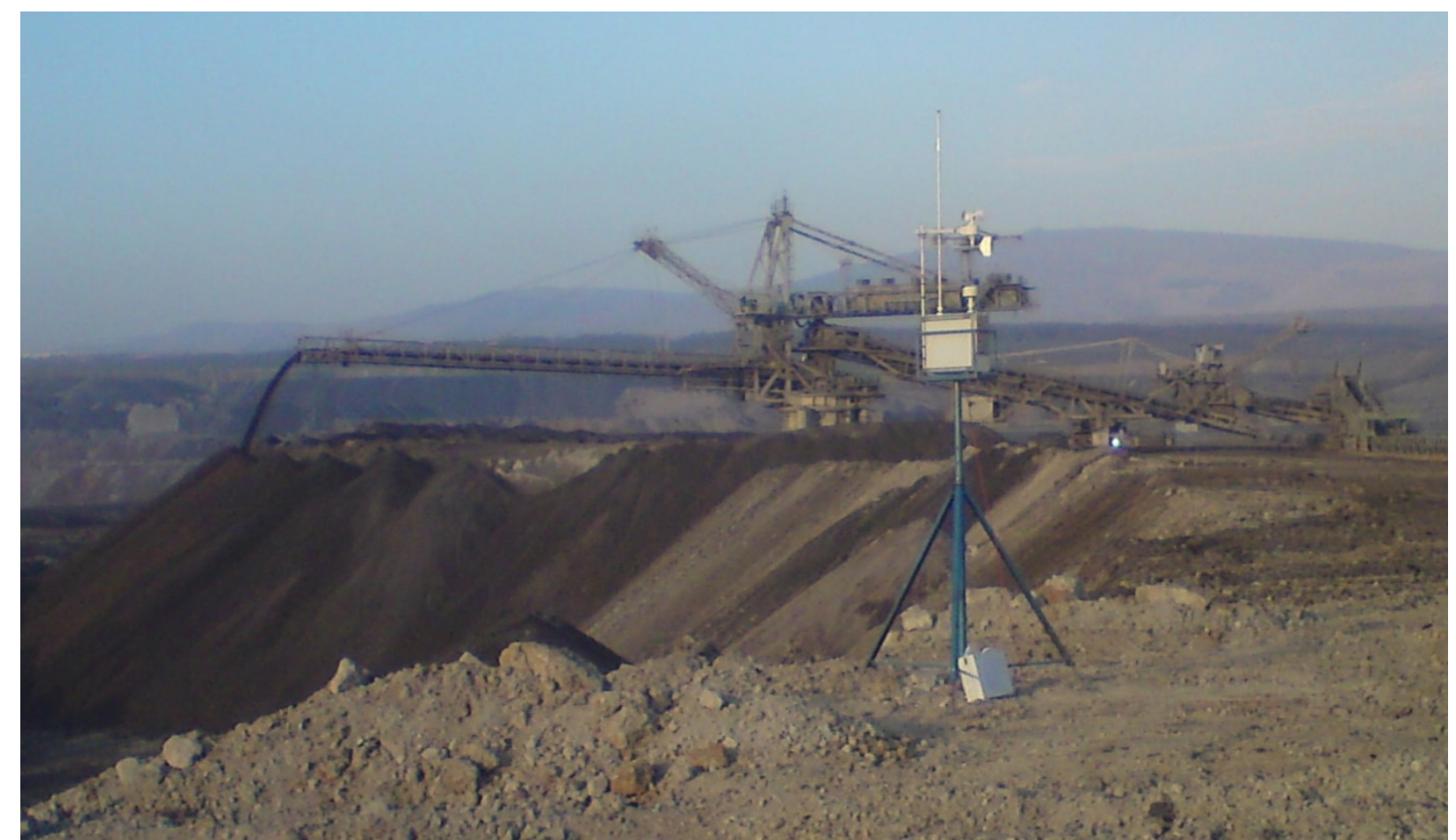

Figure 2. Stacker in the mine of Kardia field during one of the measurements campaign. One of the installed PMx monitors is also shown. 


\section{Results and Discussion}

Table 1 shows the emission factors values (as they were computed by the RDM method) and the respective values of the independent variables with possible influence to the emission factor (dependent variable) as they were measured in the field (wind speed, $\mathrm{u} \mathrm{m} / \mathrm{s}$ ) or in the laboratory after the sampling material collection in the field (moisture content $\mathrm{M} \%$, silt content s, \%).

Table 1. Emission factors (ef) and the respective values of moisture content (M, \%), silt content (s, \%), and wind speed $(\mathrm{u})$.

\begin{tabular}{ccccc}
\hline Mines & ef $(\mathbf{K g} / \mathbf{t})$ & $\mathbf{M}(\mathbf{\%})$ & $\mathbf{s}(\mathbf{\%})$ & $\mathbf{u}(\mathbf{m} / \mathbf{s})$ \\
\hline \multirow{3}{*}{ Mine of South field } & 0.003769745 & 12.37 & 33.30 & 1.88 \\
& 0.004419243 & 17.06 & 9.23 & 1.57 \\
& 0.004419243 & 12.24 & 39.47 & 1.57 \\
& 0.003292687 & 17.63 & 3.43 & 3.40 \\
& 0.008677588 & 14.17 & 6.98 & 3.20 \\
Mavropigi mine & 0.009655968 & 17.42 & 0.67 & 4.70 \\
\hline \multirow{3}{*}{ Amyntaio mine } & 0.016907607 & 42.00 & 3.26 & 8.24 \\
& 0.016907607 & 39.62 & 1.21 & 8.24 \\
& 0.000367833 & 27.06 & 5.30 & 2.79 \\
& 0.000330507 & 29.89 & 6.98 & 2.98 \\
\hline \multirow{3}{*}{ Mine of Kardia field } & 0.000385369 & 34.15 & 18.42 & 4.24 \\
& 0.038553538 & 13.57 & 1.33 & 4.20 \\
\hline & 0.039790131 & 10.95 & 2.57 & 3.60 \\
& 1.909399642 & 25.69 & 0.80 & 1.70 \\
& 1.076361360 & 16.08 & 6.70 & 2.10 \\
& 1.076361360 & 31.66 & 1.11 & 2.10 \\
& 0.000312244 & 20.10 & 0.04 & 3.00 \\
& 0.000312244 & 24.29 & 0.82 & 1.70
\end{tabular}

Using a dependent variable (the natural logarithm of emission factor (ln ef)) and independent variables (the corresponding in moisture $(\ln \mathrm{M})$, silt content $(\ln \mathrm{s})$, and wind speed $(\ln \mathrm{u})$ values), the statistically significant relationship between $\ln$ ef and each of the three independent variables was examined.

The results indicated a relatively weak relationship between $\ln$ ef and $\ln \mathrm{s}$, so we should consider removing this independent variable from the model. MLR was carried out between $\ln$ ef (dependent variable) and the two independent variables ( $\ln \mathrm{M}$ and $\ln$ $\mathrm{u})$. MLR was repeated, rejecting each time the outlier values reached $p<0.05$ and $\mathrm{R}>0.8$. Finally, the following relation was established, representing the emission factor (in $\mathrm{kg} / \mathrm{t}$ ) of PM10 emissions due to stacker.

$$
\begin{gathered}
\text { ef }=0.285 \times \frac{\mathrm{u}^{3.627}}{\mathrm{M}^{2.924},} \\
p \text { value }<0.05, \mathrm{R}^{2}=89.3 \%
\end{gathered}
$$

Since the $p$ value is less than 0.05 , there is a statistically significant relationship between the variables at the $95.0 \%$ confidence level. The R-squared statistic indicates that the fitted model explains $89.3 \%$ of the variability in the dependent variable (ef).

Figure 3 depicts the observed and predicted values in a graph. Table 2 demonstrates the unstandardized residual test of normality, indicating that unstandardized residuals follow normal distribution (Kolmogorov-Smirnov test: $p>0.2$, and Shapiro-Wilk test: $p=0.26$ ). Each such relation is provided to the end user with specific ranges of validity for the independent variables. In our case, its recommended range of application is $1.6<\mathrm{u}<8.2 \mathrm{~ms}^{-1}, \mathrm{~s}<39 \%, 11 \%<\mathrm{M}<42 \%$. 


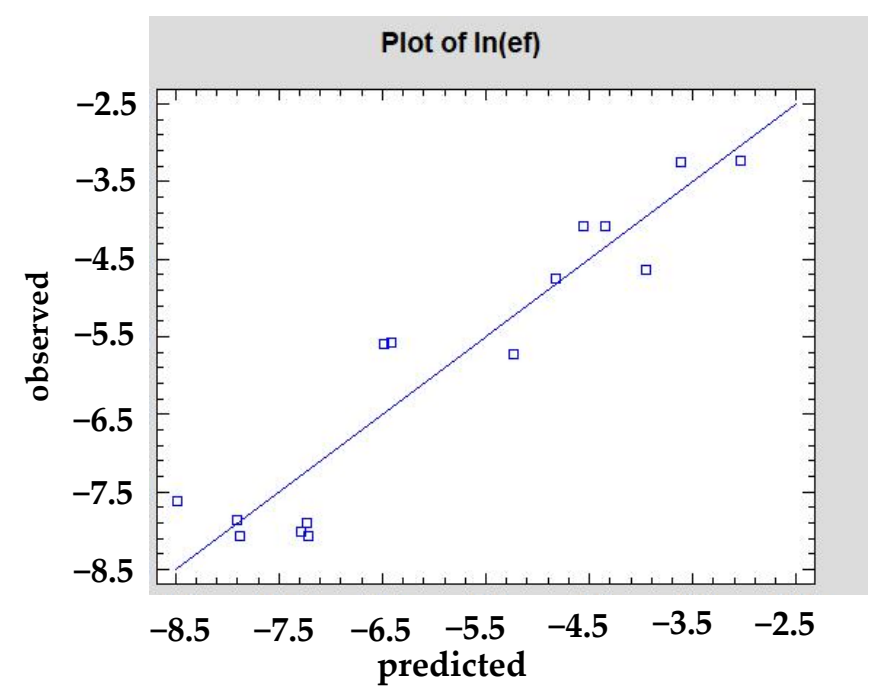

Figure 3. Observed versus predicted values graph of $\ln (\mathrm{ef})$.

Table 2. Test of normality of residuals.

\begin{tabular}{cccccccc}
\hline & \multicolumn{6}{c}{ Tests of Normality } \\
\cline { 2 - 7 } & \multicolumn{2}{c}{ Kolmogorov-Smirnov ${ }^{\text {a }}$} & \multicolumn{3}{c}{ Shapiro-Wilk } \\
\cline { 2 - 7 } & Statistic & df & Sig. & Statistic & df & Sig. \\
\hline Unstandardized Residual & 0.131 & 15 & $0.20 *^{*}$ & 0.929 & 15 & 0.260 \\
\hline
\end{tabular}

* This is a lower bound of the true significance. ${ }^{\text {a }}$ Lilliefors Significance Correction.

\section{Conclusions}

The study in four surface lignite mines indicated that stackers are significant fugitive dust emission sources. A multiple linear regression model was developed by considering the major influencing parameters, the moisture content $(\mathrm{M}, \%)$, silt content $(\mathrm{s} \%)$, and the wind speed $(\mathrm{u}, \mathrm{m} / \mathrm{s})$ to calculate PM10 emissions from this surface mining activity. The results shows that the model can be simplified by removing the independent variables $\mathrm{s}$ (silt content) from the model. The final model describes the relationship between PM10 the emission factor, and two independent variables (the moisture content $(\mathrm{M}, \%)$ and the wind speed $(\mathrm{u}, \mathrm{m} / \mathrm{s}))$. The equation of the fitted model is

$$
\text { ef }=0.285 \times \frac{\mathrm{u}^{3.627}}{\mathrm{M}^{2.924}}
$$

The $p$ value in the ANOVA table was less than 0.05 , meaning that there is a statistically significant relationship between the variables at the $95.0 \%$ confidence level. The R-squared statistic indicates that the model as fitted explains $89.3 \%$ of the variability in the dependent variable (ef). The developed model can be applied to estimate PM10 emissions from one significant emission source of a surface mine, in a range of validity for the independent variables. Furthermore, to predict the contribution of this source in the air pollution before the commencement of any mining project, effective mitigative measures and scenarios at the planning stage as well were designed.

Author Contributions: Conceptualization, A.T.; methodology, A.T.; software, I.K. and A.T.; validation, A.T., S.G. and F.P.; formal analysis, A.T.; investigation, A.T.; resources, A.T.; data curation, S.G.; writing—original draft preparation, A.T.; writing—review and editing, A.T., I.K. and S.G; visualization, A.T.; supervision, A.T. and F.P.; project administration, A.T.; funding acquisition, A.T. All authors have read and agreed to the published version of the manuscript.

Institutional Review Board Statement: Not applicable. 
Informed Consent Statement: Not applicable.

Data Availability Statement: The data presented in this study are available on request from the corresponding author.

Acknowledgments: The authors would like to thank the Lignite Center of Western Macedonia (LCWM) for the financial support of the project, and the employees of the LCWM for their help during the field experiments.

Conflicts of Interest: The authors declare no conflict of interest.

\section{References}

1. Huertas, J.I.; Huertas, M.E.; Izquierdo, S.; González, E.D. Air quality impact assessment of multiple open pit coal mines in northern Colombia. J. Environ. Manag. 2012, 93, 121-129. [CrossRef] [PubMed]

2. Sendlein, L.V.A.; Yazicigil, H.; Carlson, C.L. Surface Mining Environmental Monitoring and Reclamation Handbook; Elsevier: New York, NY, USA, 1983; pp. 373-417.

3. Ghose, M.K. Emission factors for the quantification of dust in Indian coal mines. J. Sci. Ind. Res. 2004, 634, 763-768.

4. Chaulya, S.K. Emission rate formulae for surface iron ore mining activities. Environ. Modeling Assess. 2006, 11, 361-370. [CrossRef]

5. USEPA. AP42, Compilation of Air Pollutant Emission Factors, Vol. 1: Stationary Point and Area Sources, Vol. 1, Chapter 11.9 Western Surface Coal Mining, 5th ed.; USEPA: Research Triangle Park, NC, USA, 1998.

6. USEPA. Emission Factors \& AP 42. 2009. Available online: http://www.epa.gov/ttnchie1/ap42/ (accessed on 13 July 2009).

7. Triantafyllou, A.G.; Andreadou, S.; Mousiopoulos, N.; Garas, S.; Kapageridis, I.; Tsegas, G.; Diamantopoulos, C.; Sachanidis, C.H.; Skordas, I. Surface mining in Western Macedonia, Greece:fugitive dust (PM10) emissions and dispersion. Int. J. Min. Miner. Eng. 2019, 10, 2019.

8. Triantafyllou, A.G.; Mousiopoulos, N.; Krestou, A.; Tsegas, G.; Barmpas, F.; Garas, S.; Andreadou, S. Application of inverse dispersion modelling for the determination of PM emission factors from fugitive dust sources in open-pit lignite mines. Int. J. Environ. Pollut. 2017, 62, 2017. [CrossRef]

9. Triantafyllou, A.G.; Garas, S.; Crestou, A.; Diamantopoulos, C.; Skordas, I.; Leivaditou, E.; Matthaios, V.; Proiou, D.; Coutsochristos, A.; Tzhkalios, A.; et al. Quantification of the Opencast Lignite Mines of the Lignite Centre of Western Macedonia Due to Present and Future Activities in the Sources and Receptors; Technical Report for LCWM; Public Power Corporation: Athens, Greece, 2015.

10. BS EN 15445/2008: Fugitive and Diffuse Emissions of Common Concern to Industry Sectors. Qualification of Fugitive Dust Sources by Reverse Dispersion Modeling. Available online: https://standards.iteh.ai/catalog/standards/cen/d56ee951-824c4d4f-a9f9-5df94221aae9/en-15445-2008 (accessed on 1 September 2009). 